Article

\title{
Improved Hot Smoke Processing of Chub Mackerel (Scomber japonicus) Promotes Sensorial, Physicochemical and Microbiological Characteristics
}

\author{
Md. Masud Rana ${ }^{1,+}$, Md. Mohibbullah ${ }^{1,+}{ }^{\mathbb{D}}$, , Na Eun Won ${ }^{2}$, Md. Abdul Baten ${ }^{1} \mathbb{D}_{\text {, Jae Hak Sohn }}{ }^{2}$, Jin-Soo Kim ${ }^{3, *}$ \\ and Jae-Suk Choi $2,4, *$ (D)
}

check for updates

Citation: Rana, M.M.; Mohibbullah, M.; Won, N.E.; Baten, M.A.; Sohn,

J.H.; Kim, J.-S.; Choi, J.-S. Improved Hot Smoke Processing of Chub

Mackerel (Scomber japonicus)

Promotes Sensorial, Physicochemical and Microbiological Characteristics. Appl. Sci. 2021, 11, 2629. https:// doi.org/10.3390/app11062629

Academic Editor:

Theodoros Varzakas

Received: 14 February 2021

Accepted: 12 March 2021

Published: 16 March 2021

Publisher's Note: MDPI stays neutral with regard to jurisdictional claims in published maps and institutional affiliations.

Copyright: (c) 2021 by the authors. Licensee MDPI, Basel, Switzerland. This article is an open access article distributed under the terms and conditions of the Creative Commons Attribution (CC BY) license (https:/ / creativecommons.org/licenses/by/ $4.0 /)$.
1 Department of Fishing and Post Harvest Technology, Sher-e-Bangla Agricultural University, Dhaka 1207, Bangladesh; rana.fpht@sau.edu.bd (M.M.R.); mmohib.fpht@sau.edu.bd (M.M.); mabaten.fpht@sau.edu.bd (M.A.B.)

2 Seafood Research Center, Silla University, \#605, Advanced Seafood Processing Complex, Wonyang-ro, Amnam-dong, Seo-gu, Busan 49277, Korea; ftrnd2@silla.ac.kr (N.E.W.); jhsohn@silla.ac.kr (J.H.S.)

3 Department of Seafood and Aquaculture Science, Gyeongsang National University, Tongyeong-si 53064, Korea

4 Department of Food Biotechnology, Division of Bioindustry, College of Medical and Life Sciences, Silla University, Busan 46958, Korea

* Correspondence: jinsukim@gnu.ac.kr (J.-S.K.); jsc1008@silla.ac.kr (J.-S.C.); Tel.: +82-55-772-9146 (J.-S.K.); +82-51-248-7789 (J.-S.C.)

$+\quad$ M.M.R. and M.M. contributed equally.

Abstract: Chub mackerel (CM), Scomber japonicus, is a commercially important fish species in pacific countries including South Korea and its rapid quality deterioration by various spoilage mechanisms while marketed has been reported, leading to a dramatic decline of the market price. To overcome this problem, a combination of superheated steam roasting ( $270{ }^{\circ} \mathrm{C}$ for $4 \mathrm{~min}$ ) and hot smoking $\left(70{ }^{\circ} \mathrm{C}\right)$ on $\mathrm{CM}$ fillets was applied to impart extending shelf-life at the market level. Using different sawdust with time-dependent smoking revealed that Oak sawdust at 25 min of optimized smoking time significantly $(p<0.05)$ provided the highest sensory properties (appearance, odor, color, texture and overall preferences), improved physicochemical, microbial, and nutritional properties, and subsequently, promoted shelf life of processed $\mathrm{CM}$ during the storage period at $10^{\circ} \mathrm{C}$ for up to 34 days. Moreover, the processed CM offered high nutritional value, especially, essential and nonessential amino acids were found to be 13.14 and $15.48 \mathrm{~g} / 100 \mathrm{~g}$ of CM fillets, and also reduced the trimethylamine-N-oxide level to an acceptable limit, indicating its quality and safety with high nutritional standards to end-point users upon consumption.

Keywords: chub mackerel; smoking treatment; sensory analysis; physiochemical characteristics; microbiological quality; biochemical analysis

\section{Introduction}

Worldwide, fish and fish-based products are exceptionally important elements of the human diet in respect to their unique taste and nutritional properties such as plethora of proteins and polyunsaturated fatty acids (PUFAs), which make them more precious than other terrestrial foods [1]. Based on the demand of healthy fish-food items, fish processing industries have been developed in the recent past to offer a variety of consumer products in which quality and safety are being prioritized [2]. The reason is that fish flesh is extremely vulnerable to spoilage [3]. The spoilage mechanisms in fish are attributed to the presence of a high amount of free amino acid, non-protein nitrogenous compounds (NPN) and a high post mortem $\mathrm{pH}$, which eventually support the growth of microorganisms [4]. In addition, endogenous enzymatic activity, oxidation of lipids and proteins are responsible for the quality deterioration of fish and fish products $[5,6]$. Collectively, the following spoilage 
mechanisms result in the release of various metabolites that negatively affect the sensorial attributes of the product, and simultaneously, shorten the shelf-life of products, especially in storage conditions.

Chub Mackerel (CM), Scomber japonicus, is a migratory coastal-pelagic fish species, distributed from subtropical to temperate zones of the world ocean [7]. CM has been considered as an oily fish and one of the important commercial fish species in western North Pacific [8], and it is estimated that about $10-25 \%$ of the total annual marine fish catch are from CM in Korea [9]. CM is generally marketed as a raw, dressed or processed condition like frozen fillet, and salted fish in the retail markets of South Korea [10]. Due to the presence of a rich source of PUFAs, despite applying various processing techniques, $\mathrm{CM}$ deteriorates quickly especially in tropics, so many quality and safety issues have arisen on CM products while marketed or during the storage period.

Smoking is one of the traditional and common methods of preserving fish [11], which is the combination of salting, drying and cooking processes [12]. Smoked products have an attractive and unique color and flavor, which is because of phenolic compounds and other volatile components released from plant-derived sawdust materials [13]. Additionally, superheated steam technology was employed to dry CM fillets before being processed for hot smoking. Since it is colorless and transparent hot-dry gas, the result of dried products has been evident in the preparation of foods with good textural and chemical properties [14]. When a press-cake of mackerel was prepared with superheated steam, it showed low moisture and high fatty acids contents in a previous study [15]. In the present study, we hypothesized that the combination of superheated steam and hot smoking on $\mathrm{CM}$ could provide the final products of delicacy in taste by adding attractive and favorable color, flavor and textural attributes.

The hot smoke $\left(70^{\circ} \mathrm{C}\right)$ processed products are tastier and have longer shelf lives [16], and such treatment improves physicochemical, sensorial and microbiological qualities in processed fish fillet [17], due to the presence of many beneficial complex compounds released from incomplete combustion of wood materials such as phenols, esters, ethers, alcohols, and ketones. Despite their benefits, hot smoked processed products can lead to excessive shrinkage, buckle or even splitting, which undergo decreased yield and loss of nutrients due to denaturation of dietary proteins of fish [18]. So, the optimization of time and temperature in smoking process technology is extremely important to ensure that the products are of premium quality during storage. The physical (i.e., textural profile), chemical (i.e., $\mathrm{pH}, \mathrm{VBN}, \mathrm{TBARS}$, and TMA), sensorial (i.e., organoleptic attributes), nutritional (i.e., proximate composition and fatty acids) and microbiological (i.e., TBC) characteristics have been assessed by the precedent research, where new or modified processed technology was applied to improve fish-based products $[19,20]$. However, a very limited number of studies have been investigated on CM, Scomber japonicus, or CM-based products. Considering the delicacy in taste and higher nutritional value, $\mathrm{CM}$ was selected for the current study aiming at the development of improved process technology of CM fillets with the combination of superheated steam roasting and hot smoking, for enhancing qualities of the end-product based on sensorial, physicochemical, microbiological, and nutritional aspects.

\section{Materials and Methods}

\subsection{Sample Collection and Processing}

The CM fish was bought from the local fish market, South Korea, stored with ice flakes, rinsed in the laboratory, and longitudinally cut to form a fish fillet. The size of the fillet section was $37.4 \times 7.8 \times 1.5 \mathrm{~cm}$ and the average weight of the sample was $355.2 \pm 20.91 \mathrm{~g}$.

\subsection{Pretreatment with Superheated Steam Roasting}

The CM fillets were placed in the AERO Steam Oven chamber (DFC-560A-2R/L, Naomoto Corporation, Osaka, Japan), maintaining the temperature at $270{ }^{\circ} \mathrm{C}$ for $4 \mathrm{~min}$ as followed by the previous method of Mohibbullah et al. [21]. Afterward, the roasted CM 
fillets were transferred into the polyamide bags, vacuum-packed using a vacuum sealer machine (Sambo Tech. Corporation, Gyeonggi-do, Korea), and finally stored at $4{ }^{\circ} \mathrm{C}$ until otherwise/further use.

\subsection{Smoking Treatment with Variant Sawdust}

The 24-h dip treatment was conducted for CM fillets with a brine solution of $8 \% \mathrm{NaCl}$ $\mathrm{CM}$ samples were then dried by placing at $30{ }^{\circ} \mathrm{C}$ temperature for $30 \mathrm{~min}$ and allowed to drain out excess water. After removing water, the fillets were submitted to smoking treatment. The samples were placed inside the smoking kiln (Braai Smoker, Bradley, Canada) and generated by combusting different sawdust (Apple, Chestnut, oak, Cherry and Walnut) materials. During the smoking process, the smoke temperature was recorded using a sensitive thermometer at different time intervals such as 20, 25 and $30 \mathrm{~min}$. The desired temperature was $70{ }^{\circ} \mathrm{C}$ and the smoked $\mathrm{CM}$ fillets were stored at $4{ }^{\circ} \mathrm{C}$ until analysis.

\subsection{Sensorial Properties}

The parameters such as color, odor, flavor, and overall acceptance of treated and untreated smoked products were observed and all the CM fillet samples were impartially coded preceding the sensory evaluation. These characteristics were judged by ten panelists with ages between 25 and 40, who were previously well trained about the evaluation method. During the sensory evaluation, the changes in color, flavor, odor, and overall acceptances were assessed by a 9-point hedonic scale ( 1 for extremely dislike and 9 for extremely like). The value 5 was considered as the threshold limit and values less than 5 were considered as rejected [22].

\subsection{Physical Properties}

\subsubsection{Evaluation of Odor Intensity}

Following the procedure of Macagnano et al. [23], a total of $5 \mathrm{~g}$ of sample was taken in a $50 \mathrm{~mL}$ conical flask, the lid closed with parafilm and fitted with an odor concentration meter (XP-329, New Cosmos Electric Co. Ltd., Osaka, Japan). The odor intensity was calculated by observing the signal (peak), which is expressed as an arbitrary unit.

\subsubsection{Calculation of Weight Loss}

The Goulas and Kontominas [24] method was used to calculate the weight loss of CM fillets. It was done by evaluating the differences between the weight of the samples before and after oven drying.

\subsubsection{Texture Analysis}

The texture of CM fillets was assessed by Brookfield Texture Analyzer (Massachusetts, USA), equipped with a computer software system (Texture PRO CT, Middleboro, USA). A series of parameters, explicitly hardness, chewiness, cohesiveness and springiness, were estimated by following the experiment of Ganesan and Benjakul [25].

\subsubsection{Evaluation of Color}

The CM fillet color was assessed by the CM-700d Konica Minolta (Tokyo, Japan) instrument. Using a Hunter system value, the surface color of each sample was calculated as in previous reports [26-28].

\subsection{Chemical Properties}

\subsubsection{Determination of $\mathrm{pH}$}

The homogenized CM sample (4 g) was thoroughly mixed with $45 \mathrm{~mL}$ of distilled water (DW) for $2 \mathrm{~min}$ and well centrifuged (SHG-15D, SciLab, and Seoul, Korea). The $\mathrm{pH}$ of the sample was measured using a pH meter (OHAUS STARTER 2100, Seoul, Korea) with a glass electrode. 


\subsubsection{Determination of Volatile Base Nitrogen (VBN)}

The VBN value is measured by a Conway micro diffusion method. A total of $5 \mathrm{~g}$ of sample was mixed with $25 \mathrm{~mL}$ of distilled water, filtrated, and mixed with potassium carbonate, following the method of Ali et al. [29].

\subsubsection{Determination of Thiobarbituric Acid-Reactive Species (TBARS)}

A total of $5 \mathrm{~g}$ CM fillet sample was taken and thoroughly mixed with $12.5 \mathrm{~mL}$ TBARS solution containing 20 trichloroacetic acid and $2 \mathrm{M}$ phosphoric acid, followed by filtration, incubation at $95^{\circ} \mathrm{C}$ for $30 \mathrm{~min}$, and reading the absorbance value at $530 \mathrm{~nm}$ wavelength [30].

2.6.4. Determination of Trimethylamine (TMA) Analysis by Gas Chromatography-Mass Spectrometry (GC/MS)

The presence of TMA in spoiling marine organisms is due to the bacterial degradation of TMAO. The TMA is used as a marker to assess the seafood quality because it is the primary component to producing fishy off-odor [31]. The GC/MS method was performed to estimate the value of trimethylamine $\mathrm{N}$-oxide (TMAO) in both raw and smoked CM products, as followed by Mohibbullah et al. [21]. In this analysis, $10 \mathrm{~g}$ of fish sample was mixed with $10 \mathrm{~mL}$ of distilled water, sonicated for $20 \mathrm{~min}$, filtrated, and then volatilized using GC instrument (Agilent 7890B GC, Agilent Technologies Inc., Santa Clara, CA, USA) at an oven temperature of $240{ }^{\circ} \mathrm{C}$ which increased from 40 to $210{ }^{\circ} \mathrm{C}$ following the flow rate of $10{ }^{\circ} \mathrm{C} / \mathrm{min}$. Procedures for quantification of TMAO content in raw and smoked CM fillet were followed by comparing the standard compound (Sigma Aldrich, St. Louis, MO, USA) run side-by-side.

\subsection{Microbiological Properties: Total Bacterial Count (TBC) and Total Coliform}

The ten-fold serial dilution method was used to determine the bacterial load of the $\mathrm{CM}$ fillet sample. A $1 \mathrm{~g}$ of sample was taken and transferred to a test tube containing $9 \mathrm{~mL}$ of sterile saline solution, spread quickly on the surface of plate count agar (Difco, Franklin Lakes, NJ, USA), as followed by Chen et al. [26]. The total coliform count was estimated following the preferred method of the US Food and Drug Administration (FDA) [27].

\subsection{Nutritional Properties}

\subsubsection{Analysis of Nutritional Composition}

The nutritional composition of smoked CM fillets was determined by following the method of Horwitz et al. [32], as performed in the Traditional Microorganism Resources Center, Daegu, South Korea.

\subsubsection{Analysis of Amino Acid by HPLC Method}

The samples of hot smoked CM fillets were duplicated in measurement for the estimation of amino acid content using a High-Performance Liquid Chromatography (HPLC; LC-20A, Shimadzu Corp., Kyoto, Japan) at Pukyong National University laboratory, Busan, South Korea. This method was followed by the previously published procedure of Gheshlaghi et al. [33].

\subsection{Statistical Analysis}

The statistical analysis was performed by IBM SPSS software, version 21.0 (IBM, Corp., New York, NY, USA). The data of different biochemical parameters were triplicated and calculated as mean \pm standard deviation (std). Results were considered to be statistically significant at 95\%, where the significance level was set at $p<0.05$.

\section{Results}

\subsection{Effect of Different Sawdust Smoke on Sensory Analysis}

The color and flavor of $\mathrm{CM}$ were developed through the hot smoke of different sawdust. To identify the best smoke material in the processing of $\mathrm{CM}$ fillets, two different 
smoking duration of 20 and 25 min were maintained in the present study, as followed by the previous reports $[20,21]$. The results significantly $(p<0.05)$ improved sensorial features when CM fillet was smoked by oak sawdust, followed by apple, cherry, and walnut sawdust at 20 and $25 \mathrm{~min}$, respectively (Figure 1). Therefore, based on screening results with different sawdust materials, oak sawdust was selected as the best smoking material for further study.

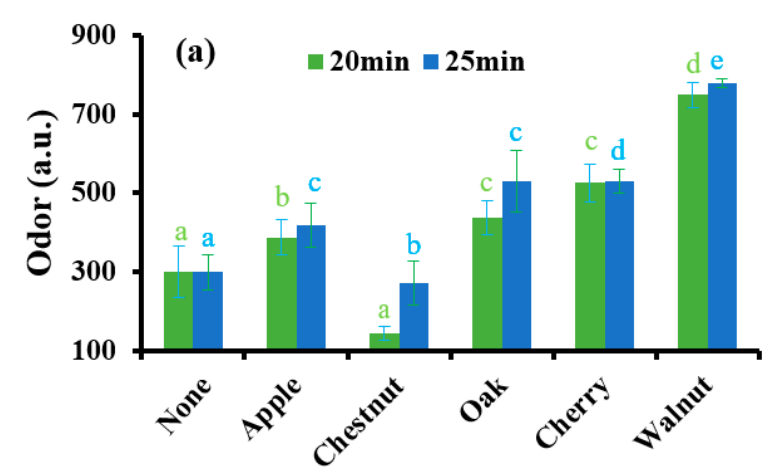

Sawdust

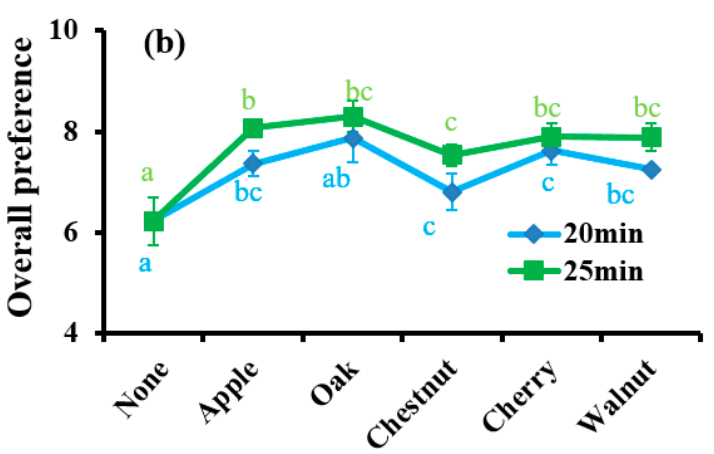

Sawdust

Figure 1. Effect of various sawdust (apple, chestnut, oak, cherry, and walnut) materials on instrumental odor intensity (a), and overall preference based on sensory attributes (b) in hot smoked chub mackerel (CM) fillet at two smoking times (20 and $25 \mathrm{~min}$ ). Data were expressed as mean \pm std $(n=10)$, where different letters were statistically different $(p<0.05)$.

\subsection{Effect of Time-Dependent Smoking on Odor and Sensory Evaluation}

The consumer's acceptability and preferences of combined treatment of superheated steam and hot smoked CM were evaluated by an instrumental odor analysis and sensorybased 9-point hedonic scale. The results indicated that the odor intensity significantly $(p<0.05)$ improved with the increased smoke time at $0,10,15,20,25$, and $30 \mathrm{~min}$. However, in the sensory analysis as performed by skilled panelists, 20 and 25 min smoke times were found to have more acceptable sensorial features such as appearance, odor, taste, and overall preferences and were optimized for the next experiment (Figure 2).
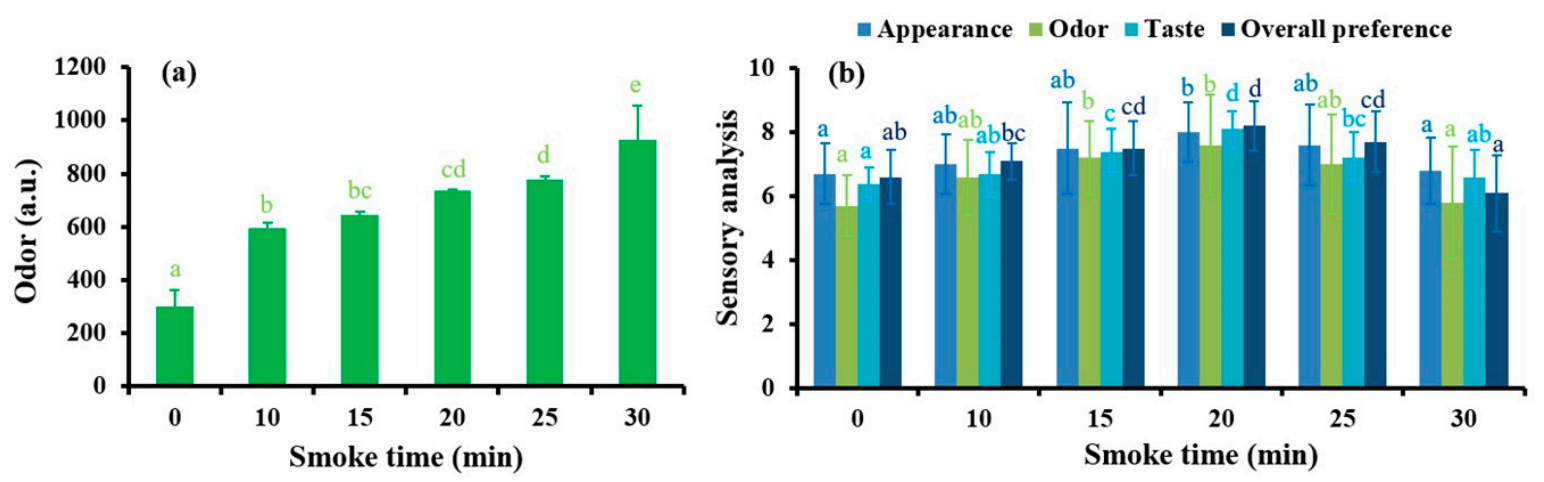

Figure 2. Changes of odor intensity (a), and sensory quality (b) in CM fillet with different smoke times $(0,15,20,25$, and $30 \mathrm{~min})$ by oak sawdust. The data were stated as mean \pm std $(n=10)$, where different letters were statistically different $(p<0.05)$.

\subsection{Effect of Smoke Temperature on Physical Features of CM Fillet}

3.3.1. Effect of Smoking Time on Weight Loss

The weight loss of processed CM revealed that there were no significant differences at 20,25 , and 30 min of smoking. In the present study, it was evident that smoking time being applied on processed CM had a non-significant effect on weight loss (Figure 3a). 

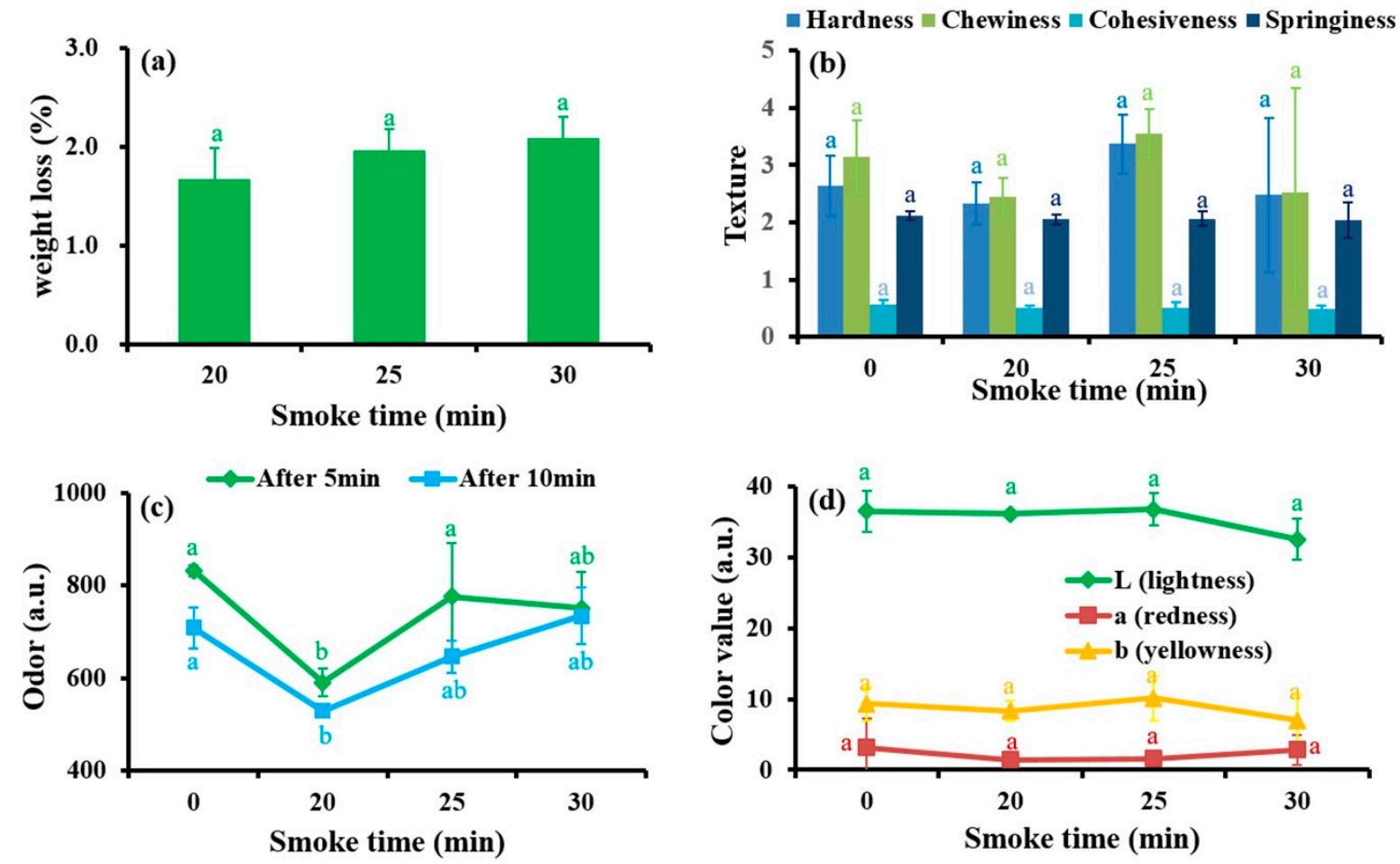

Figure 3. Changes of weight loss (a), texture analysis (b), odor (c), and color value (d) in hot smoked CM fillet products with different smoking time. The data were stated as mean $\pm \operatorname{std}(n=10)$, where different letters were statistically different $(p<0.05)$.

\subsubsection{Effect of Smoking Time on Texture}

Instrumental texture analysis of processed food products is the most essential and important measurement in the assessment of quality for consumer acceptance. Here, in time-course smoking of $0,20,25$, and $30 \mathrm{~min}$, there were no significant changes in the textural properties of hardness, chewiness, cohesiveness, and springiness of hot smoked $\mathrm{CM}$, as compared with non-smoking CM product (Figure $3 b$ ).

\subsubsection{Effect of Smoking Time on Odor}

The odor of hot smoked $\mathrm{CM}$ was estimated at each $5 \mathrm{~min}$ and $10 \mathrm{~min}$ of the interval, which significantly $(p<0.05)$ decreased in the smoking time of $20 \mathrm{~min}$. However, after 25 min smoking, odor intensity was similar to that of non-smoked CM, indicating that hot smoking did not influence the odor quality at this condition. (Figure 3c).

\subsubsection{Effect of Smoking Time on Color}

The color attribute is considered as one of the most important parameters of processed fish products, which directly reflects consumer choice. Instrumental color values are depicted as L for lightness (lightness/darkness: higher/lower), a for red/green (higher/lower), b for yellow/blue (higher/lower). All color parameter values obtained from the color meter showed insignificant differences with smoking time (0 to $30 \mathrm{~min}$ ), as compared with non-smoked $\mathrm{CM}$. The results suggested that an improved hot smoking process had no obvious effects on color changes of $\mathrm{CM}$ fillets, maintaining the original characteristics of the product appearance (Figure 3d).

\subsection{Effect of Smoking Treatment on Biochemical Properties of Processed CM}

3.4.1. Effect of Smoking Time on $\mathrm{pH}$

$\mathrm{pH}$ in processed fish products is used as an indicator for determining the quality of fishery products. Here, the $\mathrm{pH}$ level in smoked CM fillet significantly decreased $(p<0.05)$ 
with smoking time at 20, 25 and $30 \mathrm{~min}$, respectively, and reached its acceptability limit $(\mathrm{pH}=6.32-6.22)$ (Figure 4a).
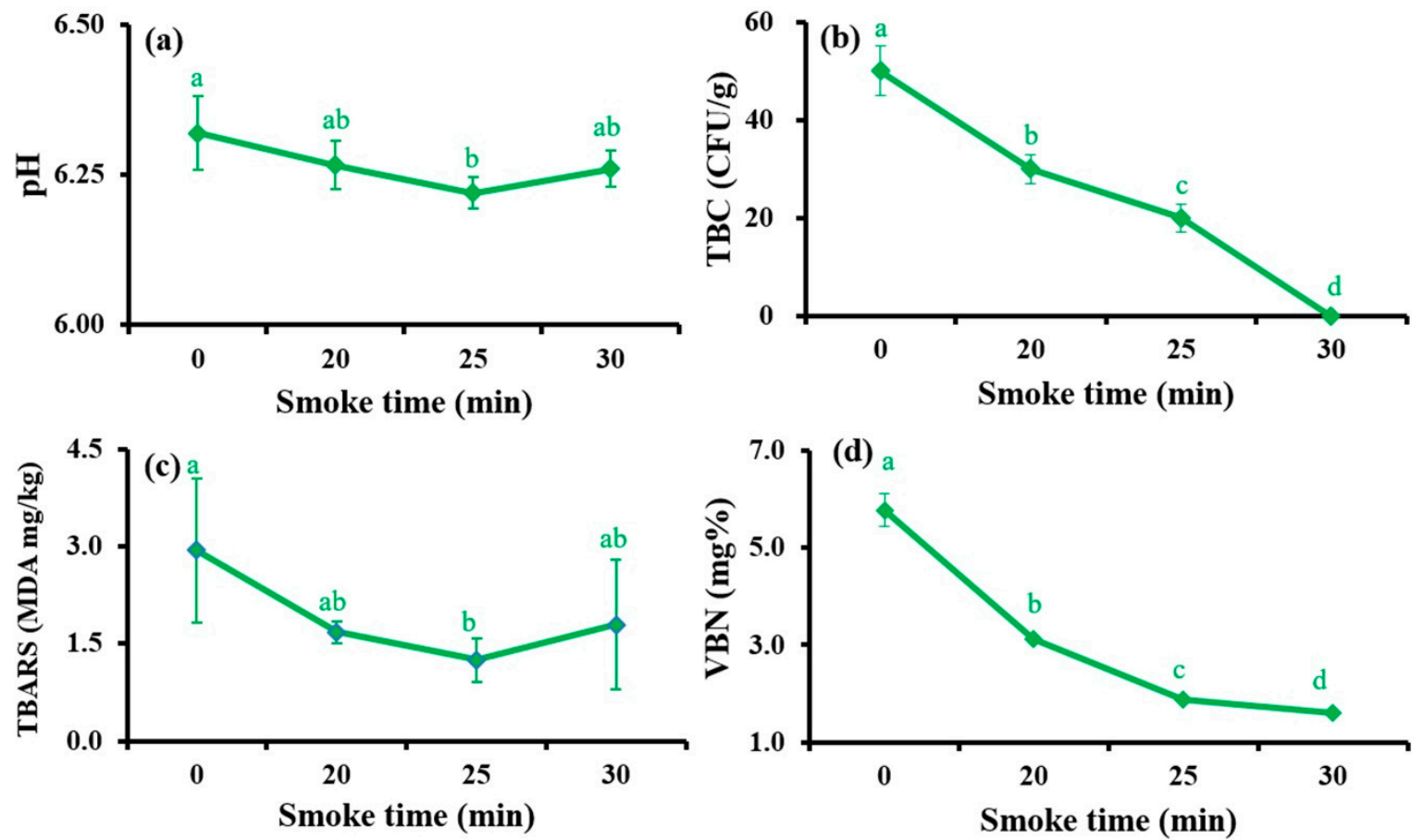

Figure 4. Changes of $\mathrm{pH}(\mathbf{a})$, total bacterial count (TBC) (b), thiobarbituric acid reactive substances (TBARS) (c), and volatile base nitrogen $(\mathrm{VBN})$ value $(\mathbf{d})$ in hot smoked CM fillet with different smoking times. The data were stated as mean \pm std $(n=10)$, where different letters were statistically different $(p<0.05)$.

\subsubsection{Effect of Smoking Time on TBC and Coliform}

The microbial quality of processed fish products is an important aspect of food safety to end-point consumers. Therefore, it is very important to assess the TBC and Coliform bacteria in hot smoked $\mathrm{CM}$ for ensuring the quality. The present study found a significant $(p<0.05)$ decrease in bacterial biomass that was assessed in smoked CM fillet with the extension of smoke time (Figure $4 b$ ).

\subsubsection{Effect of Smoking Time on TBARS Changes}

Thiobarbituric acid reactive substances (TBARS) are a convenient pathway to determine the level of fat oxidation in processed fish products and are expressed by measuring the malondialdehyde (MDA) content of the sample. The result showed that a significant $(p<0.05)$ decrease in MDA content from 0 to 25 min of smoking time and again a nonsignificant increment in MDA content at $30 \mathrm{~min}$ smoking time were found in processed CM fillet (Figure 4c).

\subsubsection{Effect of Smoking Time on VBN Changes}

In this experiment, it was found that the $\mathrm{VBN}$ of hot smoked $\mathrm{CM}$ significantly $(p<0.05)$ decreased with smoking time and the lowest VBN value was observed at $30 \mathrm{~min}$ (Figure 4d).

\subsubsection{Effect of Smoking Time on Sensory Attributes}

As performed by the trained panelists, sensory evaluation on appearance, odor, taste and overall preferences were found to be significantly $(p<0.05)$ increased at $25 \mathrm{~min}$ and further declined at $30 \mathrm{~min}$ smoking time (Figure 4e). Thus, we optimized $25 \mathrm{~min}$ smoke time for further analysis of CM fillets on the effects of storage conditions. 


\subsection{Effect of Smoking on Storage Conditions of Processed CM}

\subsubsection{Analysis of Smoked CM Microbiological Quality on Storage Duration}

The growth of food-borne microorganisms is greatly influenced by temperature. Herein, the microbiological quality of hot smoked CM fillets was characterized by TBC and coliform count and evaluated in two different storage conditions of 10 and $15{ }^{\circ} \mathrm{C}$ temperature. As shown in Table S1, no bacterial growth (CFU/g) was developed during the storage period up to 34 days, indicating that shelf-life of hot smoked CM could be extended up to 34 days without invasion of bacterial biomass at both storage temperatures 10 and $15{ }^{\circ} \mathrm{C}$.

\subsubsection{Effect of Storage Duration on VBN Changes}

The hot smoke processed CM fillets were kept at two storage conditions, 10 and $15{ }^{\circ} \mathrm{C}$ temperature for 0 to 34 days. According to Figure 5 a, the VBN value significantly $(p<0.05)$ increased with the extension of storage duration. The VBN value of smoked CM was assessed in between the ranges of $13-20.3(\mathrm{mg} \%)$ and $13-26(\mathrm{mg} \%)$ at 10 and $15^{\circ} \mathrm{C}$, respectively, throughout the storage period of 0-34 days. The study indicated that the $10{ }^{\circ} \mathrm{C}$ storage condition had better performance for preserving hot smoked CM fillets.
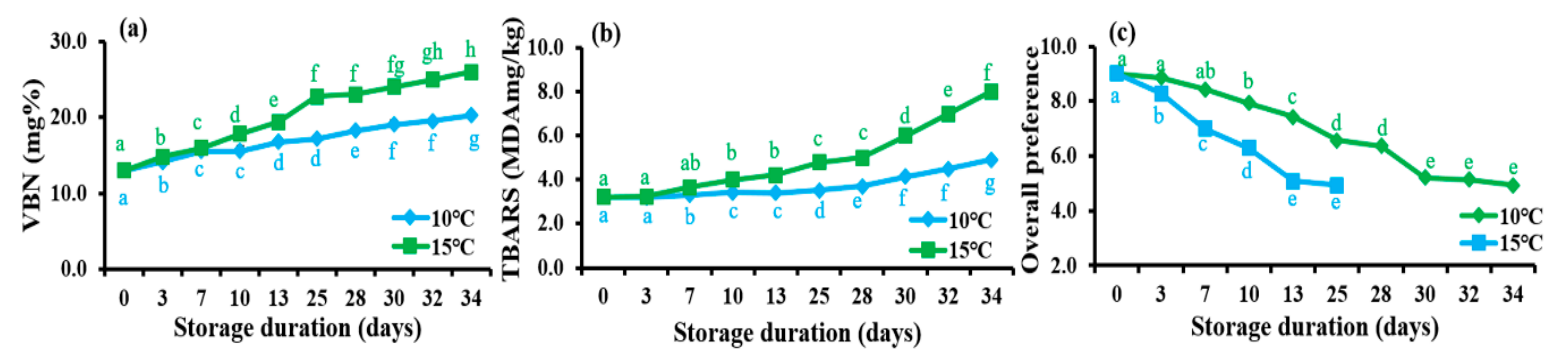

Figure 5. Changes of VBN (a), TBARS (b) and overall preference (c) value in hot smoked CM fillet at two different temperatures $\left(10\right.$ and $\left.15^{\circ} \mathrm{C}\right)$ in a storage period 0 to 34 days. The data were stated as mean \pm std $(n=10)$, where different letters were expressed as statistically different $(p<0.05)$.

\subsubsection{Effect of Storage Duration on TBARS Changes}

The TBARS value of hot smoked CM fillet was found to be significantly $(p<0.05)$ increased during the entire storage time at both storage conditions $\left(10\right.$ and $\left.15^{\circ} \mathrm{C}\right)$ and varied between $3.2-4.9$ and $3.2-8 \mathrm{mg} / \mathrm{g}$, respectively (Figure $5 \mathrm{~b}$ ). This observation supported that $\mathrm{CM}$ fillets at $25 \mathrm{~min}$ smoking were shown to have extended shelf-life when stored at $10{ }^{\circ} \mathrm{C}$ temperature condition.

\subsubsection{Effect of Storage Duration on Overall Sensory Preferences}

The overall sensory preferences of CM fillets were significantly $(p<0.05)$ decreased with the increase of storage time, from 0 to 34 days, at two different storage conditions 10 and $15^{\circ} \mathrm{C}$ (Figure 5c). The overall preference of smoked CM remained at an acceptable condition up to 32 days at $10^{\circ} \mathrm{C}$ storage temperature, whereas $\mathrm{CM}$ fillets at $15^{\circ} \mathrm{C}$ storage temperature remained safe up to 13 days and then rapidly declined in quality.

\subsection{Effect of Hot Smoking on TMA Changes}

TMA content was found as $2.25 \pm 0.29$ and $1.25 \pm 0.06 \mu \mathrm{g}$ per $100 \mathrm{~g}$ sample of both raw and hot smoked CM, respectively (Figure 6). The study revealed that hot smoking of $\mathrm{CM}$ fillets had a promising suppressive effect on TMA content, which might be the cause of inhibiting the growth of specific spoilage bacteria. 

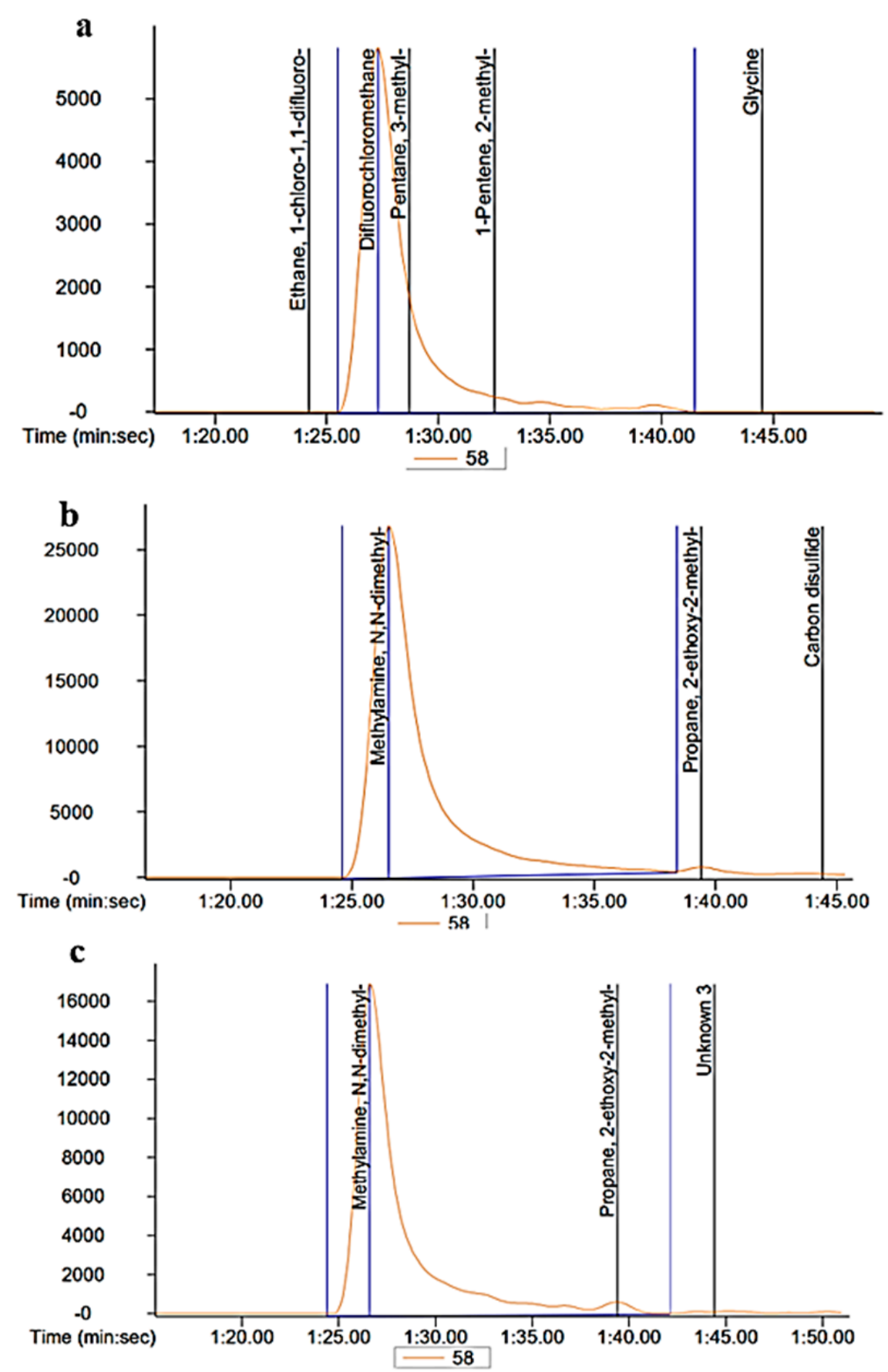

Figure 6. Effect of smoking on TMA content in CM fillets. The results were compared with (a) standard, (b) raw CM, and (c) hot smoked CM.

\subsection{Effect of Hot Smoking on Preserving Nutritional Attributes}

The nutritional quality or proximate composition of processed fish products varies with processing methods (e.g., drying, salting, and smoking), handling, and storage conditions. The protein, lipid and carbohydrate content of processed CM were 23.880, 30.288, and $0.664 \mathrm{~g} / 100 \mathrm{~g}$, respectively. The minerals viz. potassium, sodium calcium, and iron contents of hot smoked CM were reported as $296.394,270.803,67.168$, and $1.214 \mathrm{mg} / 100 \mathrm{~g}$, respectively (Table 1). 
Table 1. The nutritional quality of hot smoked CM fillet.

\begin{tabular}{ccc}
\hline Test Items & Unit & Test Results \\
\hline Calories & $\mathrm{kcal} / 100 \mathrm{~g}$ & 280.765 \\
Sodium & $\mathrm{mg} / 100 \mathrm{~g}$ & 270.803 \\
Carbohydrate & $\mathrm{g} / 100 \mathrm{~g}$ & 0.664 \\
Sugars & $\mathrm{g} / 100 \mathrm{~g}$ & 0.0037 \\
Crude fat & $\mathrm{g} / 100 \mathrm{~g}$ & 30.288 \\
Trans fat & $\mathrm{g} / 100 \mathrm{~g}$ & 0.0054 \\
Saturated fat & $\mathrm{g} / 100 \mathrm{~g}$ & 4.830 \\
Cholesterol & $\mathrm{mg} / 100 \mathrm{~g}$ & 57.236 \\
Crude Protein & $\mathrm{g} / 100 \mathrm{~g}$ & 23.880 \\
Potassium & $\mathrm{mg} / 100 \mathrm{~g}$ & 296.394 \\
Calcium & $\mathrm{mg} / 100 \mathrm{~g}$ & 67.168 \\
Iron & $\mathrm{mg} / 100 \mathrm{~g}$ & 1.214 \\
Vitamin D & $\mathrm{mg} / 100 \mathrm{~g}$ & $\mathrm{ND}$ \\
\hline
\end{tabular}

\subsection{Effect of Hot Smoking Treatment on Determination of amino Acid in Smoked CM Fillet}

The amino acid analysis is an important parameter for evaluating the protein quality of fish samples. This study identified 17 amino acids including 9 essential and 8 nonessential amino acids in hot smoked CM fillets (Table 2). Among essential amino acids, lysine $(2252.2 \mathrm{mg} / 100 \mathrm{~g})$, leucine $(2153.3 \mathrm{mg} / 100 \mathrm{~g})$ and arginine $(1736.3 \mathrm{mg} / 100 \mathrm{~g})$ were found higher, while that of glutamic acid $(3691.9 \mathrm{mg} / 100 \mathrm{~g})$, proline $(2746.0 \mathrm{mg} / 100 \mathrm{~g})$, and aspartic acid $(2213.2 \mathrm{mg} / 100 \mathrm{~g})$ were higher in the contents of non-essential amino acids found in hot smoked CM. These findings suggested that collective treatment of superheated steam roasting and hot smoking of CM fillets enriched amino acid profiles along with promoting physicochemical properties and antimicrobial performances, which ultimately rendered extension of shelf-life during the storage period.

Table 2. Amino acid content (mg/100 g) in hot smoked CM fillet.

\begin{tabular}{cc}
\hline Amino Acid & $\begin{array}{c}\text { Hot Smoked CM } \\
\text { mg/100 g }\end{array}$ \\
\hline Valine & 1347.2 \\
Methionine & 762.2 \\
Isoleucine & 997.0 \\
Leucine & 2153.3 \\
Phenylalanine & 966.7 \\
Lysine & 2252.2 \\
Histidine & 1259.4 \\
Arginine & 1736.3 \\
Threonine & 1665.4 \\
\hline EEAA & $\mathbf{1 3 , 1 3 9 . 7}$ \\
\hline Aspartic acid & 2213.2 \\
Serine & 1223.5 \\
Glutamic acid & 3691.9 \\
Glycine & 1565.1 \\
Alanine & 1349.0 \\
Cystine & 1769.4 \\
Proline & 2746.0 \\
Tyrosine & 924.1 \\
\hline ENon EAA & $\mathbf{1 5 , 4 8 1 . 9}$ \\
\hline
\end{tabular}

\section{Discussions}

Because of the large number of nutrients, including protein, long-chain omega-3 polyunsaturated fatty acids ( $n-3$ PUFAs), and micronutrients including selenium, iodine, potassium, vitamin $\mathrm{D}$ and $\mathrm{B}$, fishes are widely considered as a healthy and balanced diet for 
dietary uptake [34]. Fish is a highly perishable culinary commodity because of the fact that it becomes extremely vulnerable to oxidation resulting in the development of off-odor and -flavor and subsequent spoilage takes place while marketed [35]. Therefore, it is of need to develop or improve preservation and processing techniques more efficiently for keeping quality as well as extending the shelf-life of fish and fishery products. This study was set to the effects of combined treatment of superheated steam roasting and hot smoking $\left(70{ }^{\circ} \mathrm{C}\right)$ of $\mathrm{CM}$ in improving sensory, physicochemical, nutritional, and microbiological qualities even at storage conditions, intending to achieve the best quality product for the end-point consumers.

Sensory evaluation is one of the quickest, easiest, and most common methods to evaluate the quality of fish that can be done by human senses such as sight (color), tactility (to test the flesh elasticity), and olfaction (odor) [14]. The present study conducted a sensory assessment technique to know the consumer preferences of hot smoking $\left(70{ }^{\circ} \mathrm{C}\right)$ of Chub mackerel fillet at the different smoking time $(0,20,25$ and $30 \mathrm{~min})$ with different sawdust materials (Apple, Oak, Chestnut, Cherry and Walnut). The study found a supreme sensory quality (appearance, odor, color, texture and overall preferences) product at $25 \mathrm{~min}$ smoke time and oak sawdust as the best smoke generating materials. This study complies with the study of hot smoked Wels catfish observed by Küçükgülmez et al. [36]. Similar results were also found in our previous studies that oak sawdust provided good sensorial attributes while smoking of adductor muscle of pen shell Atrina pectinate and pacific saury Cololabis saira [20,21]. The characteristic flavor and aroma of hot smoked CM are predominantly achieved through the absorption of many volatile components from wood smoke, among which phenolics might be the most influential.

The firmness of the fish products is considered as one of the most important quality parameters to determine consumer preference [37]. The weight loss of the hot smoked CM was found unchanged at the different smoke times (20, 25, and $30 \mathrm{~min})$, which indicates good quality products, and this study was supported by Baten et al. [16,19]. Textural quality significantly affects the overall quality assessment and textural profile, which includes the assessment of hardness, springiness, cohesiveness, chewiness, adhesiveness, and gumminess of a fish product [18]. The texture attributes of hot smoked CM remained constant throughout the smoking time (20,25, and $30 \mathrm{~min})$, maintaining unique sensorial quality for the consumers, which was more or similar to the study of Mohibbullah et al. [20]. The instrumental odor and color value play an important role in the acceptance or rejection of a fish product by consumers [38]. The time and temperature of smoking treatment had no significant impact on odor and color of processed CM and the findings were similar to the previous study [39]. The $\mathrm{pH}$ is an important parameter for assessing the quality of the fish product, as low $\mathrm{pH}(<6.2)$ early in the storage indicates good nutritional status and increased shelf-life in the latter stage $[18,40]$. The present study found significantly lower and acceptable $\mathrm{pH}$ at a 25 min smoke and this is in accordance with the study of [30]. Wood smoke has antibacterial properties that retard the growth of bacteria $[13,24]$ and this study showed a similar effect when smoking time significantly decreased bacterial load.

The TBARS is a by-product of lipid peroxidation and its assay measures the MDA level in the fish sample. The lowered level of MDA content was observed in a decreasing trend with increasing smoke time. The previous study reported that smoking treatment decreased TBARS values, where the consumability range is suggested as no more than 7-8 MDA $\mathrm{mg} / \mathrm{kg}$ [30]. The VBN is considered as one of the prime indicators of raw and processed fish products to measure the degree of freshness [41]. The VBN value of hot smoked CM showed a significant decline in increasing smoke time and remained in an acceptable range as compared with the standard VBN value of fresh fish being 5-20 mg $\mathrm{N} / 100 \mathrm{~g}$ muscle [42]. The hot smoking method significantly decreased the VBN value of Japanese Spanish mackerel, Scomberomorus niphonius [17]. In storage conditions (10 and $15^{\circ} \mathrm{C}$ ), the VBN and TBARS values were found to show an increasing trend, which is in compliance with the study of Mohibbullah et al. [21] and Oğuzhan Yildiz [30]. However, the VBN and TBARS values of hot smoked CM of shelf-life retained an acceptable value of 
$17.7 \mathrm{mg} \%$ and $3.7 \mathrm{MDA} \mathrm{mg} / \mathrm{kg}$, respectively, after 32 days at $10^{\circ} \mathrm{C}$ storage temperature. The results concluded that hot smoked CM provided excellent freshness conditions and did not exceed the maximum permissible limit of VBN and TBARS values up to the storage period of 32 days. The overall sensorial impacts of CM were significantly $(p<0.05)$ decreased with increasing of storage duration either at the 10 or $15^{\circ} \mathrm{C}$ storage condition, which is an agreement with the reports suggesting that the sensory scores of smoked bonito, catfish, gwamegi and mackerel decreased with the extension of storage time [43-45]. The suppression of bacterial (TBC and Coliform) growth was observed throughout the storage period at both storage conditions $\left(10^{\circ} \mathrm{C}\right.$ and $\left.15^{\circ} \mathrm{C}\right)$. Superheated steam roasting with hot smoking treatment prevented the growth of bacterial proliferation [13,24]. It is expected that the hot smoking process may release phenolic compounds, having antioxidant and anti-microbial actions on the surface of CM fillets.

The TMA is a very efficient index for determining the degree of spoilage in fresh, processed and lightly preserved seafood [46]. The TMAO is converted into TMA in dead fish due to the action of intrinsic enzymes and bacterial action [31,47]. Considering the TMAO content in seafood, it appears to range depending on age, species, environmental factors and harvesting time [48]. The hot smoking with oak sawdust decreased the TMA content to $1.25 \mu \mathrm{g}$ per $100 \mathrm{~g}$ in smoked $\mathrm{CM}$ while comparing with raw $\mathrm{CM}$. A similar trend of results was shown by Mohibbullah, et al. [21] and Baten et al. [17,20]. The level of TMA in hot smoked CM fillets was considered safe for human consumption, when the result was compared with the maximum consumable limit of TMA value of $10 \mathrm{mg} / 100 \mathrm{~g}$ [48]. The nutritional content of $\mathrm{CM}$ was high and was found to be comparable with Mohibbullah et al. [21]. It is evident that hot smoking treatment increased the crude protein, crude lipid, crude fiber, ash, and other minerals contents by reducing the moisture content, as can be seen in the present CM product and which is comparable to other fish and meat products [49-51]. In addition, the amino acid profile provides essential and non-essential amino acids, and it is determined that the quality of a protein is also beneficial to the human diet [52]. The amino acids and peptides are important components for the development of seafood flavor [53]. The hot smoked Chub mackerel consists of 17 amino acids, of which 9 are essential acids and 8 non-essential amino acids. The results observed in the present study are to some extent similar to Adeyeye et al. [12], who found 18 amino acids in five hot smoked processed fish. Superheated steam roasting with hot smoking treatment significantly increased the lysine and other essential amino acids in CM products, when compared with other processing techniques [54].

\section{Conclusions}

The improved process technology of $\mathrm{CM}$, namely a combination of superheated steam roasting $\left(270^{\circ} \mathrm{C}\right.$ for $\left.4 \mathrm{~min}\right)$ with hot smoking $\left(70^{\circ} \mathrm{C}\right)$, was employed in the present study. Among different sawdust materials to smoke superheated steam roasted CM fillets with time-dependent smoking, oak sawdust showed better sensory characteristics at an optimal smoke time of $25 \mathrm{~min}$. The processed CM fillets with time-dependent smoke provided desirable odor intensity, negligible impact on weight loss, insignificant color changes, and acceptable textural properties, especially, after smoking at $25 \mathrm{~min}$. With this condition, the processed $\mathrm{CM}$ also suppressed $\mathrm{pH}, \mathrm{TBC}, \mathrm{VBN}$, and TBARS values to an acceptable limit at the smoke duration of $25 \mathrm{~min}$. At 25 min smoking time, hot smoked CM was extremely good, and able to preserve its chemical properties and inhibit microbial spoilage successfully at $10^{\circ} \mathrm{C}$ up to 32 days in storage condition. Considering the quantity and quality, hot smoked CM posed a significant source of valuable nutrients (protein, lipid, and minerals), especially essential and non-essential amino acids. Moreover, hot smoked CM contained a lower and negligible amount of TMA compared to raw CM and may be considered as a safe item for human consumption. Therefore, this combined process technology could be effectively utilized by processors to increase the storage-ability of $\mathrm{CM}$ with safe and healthy conditions at the consumer level. 
Supplementary Materials: The following are available online at https:/ / www.mdpi.com/2076-341 7/11/6/2629/s1, Table S1: Microbial growth in storage condition of hot smoked CM.

Author Contributions: Conceptualization, J.-S.K., J.H.S. and J.-S.C.; methodology, J.-S.C. and J.H.S.; validation, J.H.S. and J.-S.C.; formal analysis, M.M.R., N.E.W., M.M. and M.A.B.; investigation, N.E.W. and J.-S.C.; resources, M.M.R., N.E.W. and J.-S.C.; data curation, M.M. and J.-S.C.; writingoriginal draft preparation, M.M.R., M.A.B. and M.M.; writing-review and editing, M.M. and J.-S.C.; visualization, M.M. and J.-S.C.; supervision, J.-S.K., J.H.S. and J.-S.C.; project administration, J.-S.K., J.H.S. and J.-S.C.; funding acquisition, J.-S.K., J.H.S. and J.-S.C. All authors have read and agreed to the published version of the manuscript.

Funding: This study was funded by the Ministry of Oceans and Fisheries, Korea, under the project no. PJT200885 entitled "Development and commercialization of traditional seafood products based on the Korean coastal marine resources".

Institutional Review Board Statement: Not applicable.

Informed Consent Statement: Not applicable.

Data Availability Statement: Not applicable.

Conflicts of Interest: The authors declare no conflict of interest.

\section{References}

1. Mei, J.; Ma, X.; Xie, J. Review on natural preservatives for extending fish shelf life. Foods 2019, 8, 490. [CrossRef]

2. Hicks, D.T. Seafood safety and quality: The consumer's role. Foods 2016, 5, 71. [CrossRef]

3. Hong, H.; Regenstein, J.M.; Luo, Y. The importance of ATP-related compounds for the freshness and flavor of post-mortem fish and shellfish muscle: A review. Crit. Rev. Food Sci. Nutr. 2017, 57, 1787-1798. [CrossRef] [PubMed]

4. Chaillou, S.; Chaulot-Talmon, A.; Caekebeke, H.; Cardinal, M.; Christieans, S.; Denis, C.; Desmonts, M.H.; Dousset, X.; Feurer, C.; Hamon, E.; et al. Origin and ecological selection of core and food-specific bacterial communities associated with meat and seafood spoilage. ISME J. 2015, 9, 1105-1118. [CrossRef] [PubMed]

5. Jiang, D.; Liu, Y.; Jiang, H.; Rao, S.; Fang, W.; Wu, M.; Yuan, L.; Fang, W. A novel screen-printed mast cell-based electrochemical sensor for detecting spoilage bacterial quorum signaling molecules ( $\mathrm{N}$-acyl-homoserine-lactones) in freshwater fish. Biosens. Bioelectron. 2018, 102, 396-402. [CrossRef]

6. Hematyar, N.; Rustad, T.; Sampels, S.; Kastrup Dalsgaard, T. Relationship between lipid and protein oxidation in fish. Aquac. Res. 2019, 50, 1393-1403. [CrossRef]

7. Lee, K.; Go, S.; Jung, S. Simulation-based yield-per-recruit analysis of chub mackerel Scomber japonicus in Korean waters. Korean J. Fish. Aquat. Sci. 2018, 51, 313-320. [CrossRef]

8. Go, S.; Lee, K.; Jung, S. A Temperature-Dependent Growth Equation for Larval Chub Mackerel (Scomber japonicus). Ocean Sci. J. 2020, 55, 157-164. [CrossRef]

9. Hwang, S.D.; Kim, J.Y.; Lee, T.W. Age, growth, and maturity of chub mackerel of Korea. N. Am. J. Fish. Manag. 2008, 28, 1414-1425. [CrossRef]

10. Bak, T.J.; Jeon, C.H.; Kim, J.H. Occurrence of anisakid nematode larvae in chub mackerel (Scomber japonicus) caught off Korea. Int. J. Food Microbiol. 2014, 191, 149-156. [CrossRef] [PubMed]

11. Swatawati, F.; Suzuki, T.; Dewi, E.N. The effect of liquid smoke on the quality and omega-3 fatty acids content of tuna fish (Euthynnus affinis). J. Coast. Dev. 2000, 3, 573-579.

12. Adeyeye, S.A.; Fayemi, O.E.; Adebayo-Oyetoro, A.O. Amino acid, vitamin and mineral profiles of smoked fish as affected by smoking methods and fish types. J. Culin. Sci. Technol. 2019, 17, 195-208. [CrossRef]

13. Bashir, K.M.; Kim, J.S.; An, J.H.; Sohn, J.H.; Choi, J.S. Natural food additives and preservatives for fish-paste products: A review of the past, present, and future states of research. J. Food Qual. 2017, 1-31. [CrossRef]

14. Yu, L.C.; Zzaman, W.; Akanda, M.J.; Yang, T.A.; Easa, A.M. Influence of superheated steam cooking on proximate, fatty acid profile, and amino acid composition of catfish (Clarias batrachus) fillets. Turk. J. Fish. Aquat. Sci. 2017, 17, 935-943. [CrossRef]

15. Bórquez, R.M.; Canales, E.R.; Quezada, H.R. Drying of fish press-cake with superheated steam in a pilot plant impingement system. Dry. Technol. 2008, 26, 290-298. [CrossRef]

16. Aremu, M.O.; Namo, S.B.; Salau, R.B.; Agbo, C.O.; Ibrahim, H. Smoking methods and their effects on nutritional value of African Catfish (Clarias gariepinus). Open Nutraceuticals J. 2013, 6. [CrossRef]

17. Baten, M.A.; Won, N.E.; Mohibbullah, M.; Yoon, S.J.; Hak Sohn, J.; Kim, J.S.; Choi, J.S. Effect of hot smoking treatment in improving Sensory and Physicochemical Properties of processed Japanese Spanish Mackerel Scomberomorus niphonius. Food Sci. Nutr. 2020, 7, 3957-3968. [CrossRef]

18. Sutikno, L.A.; Bashir, K.M.; Kim, H.; Park, Y.; Won, N.E.; An, J.H.; Jeon, J.H.; Yoon, S.J.; Park, S.M.; Sohn, J.H.; et al. Improvement in physicochemical, microbial, and sensory properties of common Squid (Todarodes pacificus Steenstrup) by superheated steam roasting in combination with smoking treatment. J. Food Qual. 2019, 2019, 8721725. [CrossRef] 
19. Huang, X.H.; Qi, L.B.; Fu, B.S.; Chen, Z.H.; Zhang, Y.Y.; Du, M.; Dong, X.P.; Zhu, B.W.; Qin, L. Flavor formation in different production steps during the processing of cold-smoked Spanish mackerel. Food Chem. 2019, 286, 241-249. [CrossRef]

20. Baten, M.A.; Won, N.E.; Sohn, J.H.; Kim, J.S.; Mohibbullah, M.; Choi, J.S. Improvement of Sensorial, Physicochemical, Microbiological, Nutritional and Fatty Acid Attributes and Shelf Life Extension of Hot Smoked Half-Dried Pacific Saury (Cololabis saira). Foods 2020, 9, 1009. [CrossRef] [PubMed]

21. Mohibbullah, M.; Won, N.E.; Jeon, J.H.; An, J.H.; Park, Y.; Kim, H.; Bashir, K.M.; Park, S.M.; Kim, Y.S.; Yoon, S.J.; et al. Effect of superheated steam roasting with hot smoking treatment on improving physicochemical properties of the adductor muscle of pen shell (Atrina pectinate). Food Sci. Nutr. 2018, 5, 1317-1327. [CrossRef] [PubMed]

22. Li, M.; Wang, W.; Fang, W.; Li, Y. Inhibitory effects of chitosan coating combined with organic acids on Listeria monocytogenes in refrigerated ready-to-eat shrimps. J. Food Prot. 2013, 76, 1377-1383. [CrossRef] [PubMed]

23. Macagnano, A.; Careche, M.; Herrero, A.; Paolesse, R.; Martinelli, E.; Pennazza, G.; Carmona, P.; D'amico, A.; Di Natale, C. A model to predict fish quality from instrumental features. Sens. Actuators B Chem. 2005, 111, 293-298. [CrossRef]

24. Goulas, A.E.; Kontominas, M.G. Effect of salting and smoking-method on the keeping quality of chub mackerel (Scomber japonicus): Biochemical and sensory attributes. Food Chem. 2005, 93, 511-520. [CrossRef]

25. Ganesan, P.; Benjakul, S. Effect of glucose treatment on texture and colour of pidan white during storage. J. Food Sci. Technol. 2014, 51, 729-735. [CrossRef]

26. Chen, Y.; Wu, S.; Pan, S. Effect of water-soluble chitosan in combination with glutathione on the quality of pen shell adductor muscles. Int. J. Biol. Macromol. 2015, 72, 1250-1253. [CrossRef]

27. Feng, P.; Weagant, S.D.; Grant, M.A.; Burkhardt, W.; Shellfish, M.; Water, B. BAM: Enumeration of Escherichia Coli and the Coliform Bacteria. Bacteriological Analytical Manual. 2002. Available online: http:/ /www.fda.gov/Food/FoodScienceResearch/ LaboratoryMethods/ucm064948.htm (accessed on 2 January 2021).

28. Bashir, K.M.; Park, Y.J.; An, J.H.; Choi, S.J.; Kim, J.H.; Baek, M.K.; Kim, A.; Sohn, J.H.; Choi, J.S. Antioxidant properties of Scomber japonicus hydrolysates prepared by enzymatic hydrolysis. J. Aquat. Food Prod. Technol. 2018, 27, 107-121. [CrossRef]

29. Ali, M.Y.; Hossain, S.Z.; Rashed, M.A.; Khanom, M.; Sarower, M.G. Protein loss due to post-harvest handling of shrimp (Penaeus monodon) in the value chain of Khulna region in Bangladesh. Int. J. Eng. 2013, 3, 2305-8269.

30. Oğuzhan Yildiz, P. Effect of essential oils and packaging on hot smoked rainbow trout during storage. J. Food Process. Preserv. 2015, 39, 806-815. [CrossRef]

31. Venugopal, V. (Ed.) Seafood Processing: Adding Value through Quick Freezing, Retortable Packaging and Cook-Chilling; CRC Press: Boca Raton, FL, USA, 2005.

32. Horwitz, W.; Chichilo, P.; Reynolds, H. Official Methods of Analysis of the Association of Official Analytical Chemists; Association of Official Analytical Chemists: Washington, DC, USA, 1970.

33. Gheshlaghi, R.; Scharer, J.M.; Moo-Young, M.; Douglas, P.L. Application of statistical design for the optimization of amino acid separation by reverse-phase HPLC. Anal. Biochem. 2008, 383, 93-102. [CrossRef]

34. Weichselbaum, E.; Coe, S.; Buttriss, J.; Stanner, S. Fish in the diet: A review. Nutr. Bull. 2013, 38, 128-177. [CrossRef]

35. Sampels, S. The effects of processing technologies and preparation on the final quality of fish products. Trends Food Sci. Technol. 2015, 44, 131-146. [CrossRef]

36. Küçükgülmez, A.; Eslem Kadak, A.; Celik, M. Fatty acid composition and sensory properties of Wels catfish (Silurus glanis) hot smoked with different sawdust materials. Int. J. Food Sci. Technol. 2010, 45, 2645-2649. [CrossRef]

37. Oz, A.T.; Ulukanli, Z.; Bozok, F.; Baktemur, G. The postharvest quality, sensory and shelf life of a Garicus Bisporus in active map. J. Food Process. Preserv. 2015, 39, 100-106. [CrossRef]

38. Nollet, L.M.; Toldrá, F. Handbook of Seafood and Seafood Products Analysis; CRC Press: Boca Raton, FL, USA, 2009.

39. Zzaman, W.; Bhat, R.; Yang, T.A.; Easa, A.M. Influences of superheated steam roasting on changes in sugar, amino acid and flavour active components of cocoa bean (Theobroma cacao). J. Sci. Food Agric. 2017, 97, 4429-4437. [CrossRef]

40. Abbas, K.A.; Mohamed, A.; Jamilah, B.; Ebrahimian, M. A review on correlations between fish freshness and $\mathrm{pH}$ during cold storage. Am. J. Biochem. Biotechnol. 2008, 4, 416-421. [CrossRef]

41. Senapati, M.; Sahu, P.P. Onsite fish quality monitoring using ultra-sensitive patch electrode capacitive sensor at room temperature. Biosens. Bioelectron. 2020, 168, 112570. [CrossRef]

42. Huss, H.H. Fresh Fish-Quality and Quality Changes: A Training Manual Prepared for the FAO/DANIDA Training Programme on Fish Technology and Quality Control; Food \& Agriculture Organization: Rome, Italy, 1988.

43. Koral, S.; Köse, S.; Tufan, B. The effect of storage temperature on the chemical and sensorial quality of hot smoked Atlantic bonito (Sarda sarda, Bloch, 1838) packed in aluminium foil. Turk. J. Fish. Aquat. Sci. 2010, 10, 439-443. [CrossRef]

44. Yanar, Y. Quality changes of hot smoked catfish (Clarias gariepinus) during refrigerated storage. J. Muscle Foods 2007, 18, 391-400. [CrossRef]

45. Kolodziejska, I.; Niecikowska, C.; Januszewska, E.; Sikorski, Z.E. The microbial and sensory quality of mackerel hot smoked in mild conditions. LWT Food Sci. Technol. 2002, 35, 87-92. [CrossRef]

46. Iheagwara, M.C. Effect of ginger extract on stability and sensorial quality of smoked mackerel (Scomber scombrus) fish. J. Nutr. Food Sci. 2013, 3, 199. [CrossRef]

47. Rodríguez, C.J.; Besteiro, I.; Pascual, C. Biochemical changes in freshwater rainbow trout (Oncorhynchus mykiss) during chilled storage. J. Sci. Food Agric. 1999, 79, 1473-1480. [CrossRef] 
48. Stansby, M.E. Industrial Fishery Technology; A Survey of Methods for Domestic Harvesting, Preservation, and Processing of Fish Used for Food and for Industrial Products; Reinhold Pub: New York, NY, USA, 1963; pp. 339-349. [CrossRef]

49. Oparaku, N.F.; Mgbenka, B.O. Effects of electric oven and solar dryer on a proximate and water activity of Clarias gariepinus fish. Eur. J. Sci. Res. 2012, 81, 139-144.

50. Ahmed, A.; Dodo, A.; Bouba, A.M.; Clement, S.; Dzudie, T. Influence of traditional drying and smoke-drying on the quality of three fish species (Tilapia nilotica, Silurus glanis and Arius parkii) from Lagdo Lake, Cameroon. J. Anim. Vet. Adv. 2011, 10, 301-306.

51. Foline, O.F.; Rachael, A.M.; Iyabo, B.E.; Fidelis, A.E. Proximate composition of catfish (Clarias gariepinus) smoked in Nigerian stored products research institute (NSPRI): Developed kiln. Int. J. Fish. Aquac. 2011, 3, 96-98.

52. Pratama, R.I.; Rostini, I.; Rochima, E. Amino Acid Profile and Volatile Flavour Compounds of Raw and Steamed Patin Catfish (Pangasius hypophthalmus) and Narrow-barred Spanish Mackerel (Scomberomorus commerson). In IOP Conference Series: Earth and Environmental Science; IOP Publishing: Bristol, UK, 2018; Volume 116, No. 1; p. 012056. [CrossRef]

53. Deng, Y.; Luo, Y.; Wang, Y.; Zhao, Y. Effect of different drying methods on the myosin structure, amino acid composition, protein digestibility and volatile profile of squid fillets. Food Chem. 2015, 171, 168-176. [CrossRef] [PubMed]

54. Huda, N.; Dewi, R.S.; Ahmad, R. Proximate, color and amino acid profile of Indonesian traditional smoked catfish. J. Fish. Aquat. Sci. 2010, 5, 106-112. [CrossRef] 